\title{
О НЕКОТОРЫХ ВОПРОСАХ НОВАЦИЙ ИЗБИРАТЕЛЬНОГО ЗАКОНОДАТЕЛЬСТВА РОССИЙСКОЙ ФЕДЕРАЦИИ
}

\section{ON SOME ISSUES OF INNOVATIONS IN THE ELECTORAL LEGISLATION OF THE RUSSIAN FEDERATION}

\section{Malyshenko}

Summary: Information technologies bring changes in various spheres of human life, not leaving in the shadow such democratic processes as elections to government bodies. The article discusses the innovations of the electoral legislation of the Russian Federation, identifies the problems arising with changes in the electoral legislation, and also provides the experience of foreign democratic countries in the field of electoral law. The article presents the opinions of various authors regarding legislative innovations on the election of government bodies of the Russian Federation and the constituent entities of the Russian Federation and touches upon the problems of legislation related to the possibility of remote and multi-day voting.

Keywords:electoral legislation, elections, voting, multi-day, remote voting.
Малышенко Виктор Анатольевич

Председатель, комитет по государственному устройству, местному самоуправлению, законности и вопросам государственной службы Народного Хурала Республики Бурятия, г. Улан-Удэ malyshenko2004@mail.ru

Аннотация: Информационные технологии приносят изменения в разные сферы человеческой жизни, не оставляя в тени такие демократические процессы как выборы в органы государственной власти. В статье рассмотрены новации избирательного законодательства Российской Федерации, обозначены проблемы, возникающие с изменениями в избирательном законодательстве, а также приведен опыт работы зарубежных демократических стран в области избирательного права.

В статье приведены мнения различных авторов, касающиеся законодательных новаций по избранию органов государственной власти Российской Федерации и субъектов Российской Федерации, затронуты проблемы законодательства, связанные с возможностью дистанционного и многодневного голосования.

Ключевые слова: избирательное законодательство, выборы, голосование, многодневное, дистанционное голосование.

власти народа являются референдум и свободные выборы.» [9] Выборы в России проводятся в соответствии со следующими принципами: свободные, всеобщие, прямые, равные, альтернативные при тайном голосовании. Современная избирательная система Российского государства, достаточно часто корректируется, особенно в последнее время. Внесены серьезные изменения, которые будут влиять на политические процессы. Насколько благоприятны эти изменения для формирования прозрачных институтов избирательных процессов и отражения интересов общества покажет время. Широкое применение получают системы электронного голосования. Избирательным законодательством Российской Федерации закреплено использование Государственной автоматизированной системы Российской Федерации (ГАС «Выборы») при проведении выборов и референдума. ГАС «Выборы» служит платформой для развития электронной системы голосования. Для этого используют комплексы обработки избирательных бюллетеней (КОИБ) и комплексы для электронного голосования (КЭГ).

Изучая опыт демократических стран, в данном вопросе, следует отметить, что он достаточно широк и неоднозначен. По мнению В.О. Моториной, из опыта зарубежных стран можно выявить ряд достоинств электронного голосования: 
1. Возможность голосования вне зависимости от места нахождения избирателя;

2. При использовании электронного голосования, можно минимизировать затраты на проведение выборов;

3. Значительное сокращение времени на подведение итогов выборов.

Наряду с достоинствами, по мнению автора, у электронного голосования есть ряд недостатков, таких как:

1. Система передачи информации по каналам всемирной сети уязвима с точки зрения потенциальных компьютерных сбоев и атак;

2. Недостаточно развитая нормативно-правовая база, проведения электронного голосования;

3. Несоблюдение принципа тайны волеизьявления и фактическое превращение голосования в поименное (электронная аутентификация избирателя, позволяет достаточно легко идентифицировать личность конкретного гражданина при голосовании) [1].

Интернет голосование как система волеизъявления появилась в США и странах Европы. Определенные успехи в этой области можно отметить у Эстонии. В начале 21 века была принята нормативная база, состоящая из четырех нормативно-правовых актов: «О выборах в местные органы государственной власти», «О выборах в Рийгикогу», «О выборах в Европейский парламент», «О референдуме» и создана соответствующая материально-техническая инфраструктура [2]. Особенностью эстонской модели голосования является проведение интернет-голосования только в период от шести до четырех дней до официально назначенной даты выборов. Это решение позволяет не допустить перегрузки сервера непосредственно в день голосования.

Первой международной межправительственной организацией, которая занимается проблемой отсутствия международно-правового регулирования процедур электронного голосования стал Совет Европы, который впервые в истории международного права установил стандарты электронного голосования.

Дискуссия по поводу электронного голосования привела к тому, что 3 марта 2009 года Конституционный суд ФРГ запретил использование компьютеров для голосования, признал электронное голосование не соответствующим принципам честных и открытых выборов, обязал органы власти вернуться к традиционной системе голосования. Решение объяснялось тем, что граждане должны иметь возможность без специальных технических знаний иметь возможность проверить результаты собственного голосования [3].

Не смотря на то, что высокие технологии за прошед- шее десятилетие шагнули далеко вперед, а надежность сетевых транзакций, сохранность данных и механизмы защиты персональных данных возросли, в Германии по каким-то причинам не спешат возвращаться к обсуждению возможности использования дистанционных процедур в выборном процессе [8].

Следует отметить, что не смотря на замечания в работе электронных систем дистанционного голосования эксперименты по тестированию данных систем продолжаются. Есть такой опыт в Австралии на выборах в Новом Южном Уэльсе и Канаде на муниципальных выборах в провинции Онтарио.

При этом масштаб страны, как выясняется не имеет решающего значения: безусловно успешным признан опыт применения электронных процедур и в маленькой Эстонии, и в огромной Бразилии. В обеих странах электронный способ подачи голосов является основным.

Ряд стран, ранее проводивших аналогичные эксперименты и получивших негативный опыт, остались ретроградами. К таким можно отнести Великобританию, Бельгию, Голландию, где эксперименты прекратились еще в начале нулевых годов, когда надежных технологий, способных обеспечить работу электронных избирательных процессов еще не было.

Отечественный опыт тоже не однозначен. 8 сентября 2019 года на выборах в Мосгордуму прошло первое в России дистанционное электронное голосование. В трех одномандатных избирательных округах №1, №10 и №30. Система была разработана Департаментом информационных технологий города Москвы и была применена несмотря на технические сбои при тестировании. Надо отметить, что результаты голосования по 30 одномандатному округу отличались от обычного традиционного голосования и повлияли на результаты выборов. Более 30 процентов времени система не работала, либо имела сбои, при этом более 1 тысячи человек испытали трудности с дистанционным голосованием [7].

Больше 53 процентов избирателей в 30 округе были сотрудниками бюджетных организаций. При этом, система не была защищена от регистрации фейковых избирателей. Из выводов итогов голосования по данным доклада Романа Юнемана можно отметить:

1. Закон Москвы о дистанционном электронном голосовании был принят ранее федерального закона устанавливающего такую процедуру;

2. Вместо избирательной комиссии фактическим организатором голосования выступил Департамент информационных технологий города Москвы;

3. В результате применения дистанционного электронного голосования зарегистрированные кандидаты оказались в неравном положении; 
4. Возможность проводить реальное наблюдение за ходом голосования была ограничена;

5. При подведении итогов голосования были расхождения с контрольными значениями. По данным Юнемана, кроме утечек персональных данных избирателей серьезной проблемой остается возможность персонального контроля за волеизъявлением избирателя, что нарушает процедуру тайного голосования. В первую очередь должен быть решен вопрос обеспечения тайны голосования, нормативного регулирования процедуры интернет-голосования, защиты от манипуляции. Важным значением остается доверие граждан к такому виду голосования [1].

По моему мнению, существенные новации в избирательных процедурах, таких как, применение дистанционного электронного голосования на выборах, не может быть применено без учета мнения важных участников политических процессов - политических партий.

21 июля 2020 года Государственной Думой Федерального Собрания Российской Федерации принят Федеральный Закон №Ф3-267 «О внесении изменений в отдельные законодательные акты Российской Федерации» [6], которым вносятся изменения в статьи 22 и 29 Федерального Закона «Об основных гарантиях избирательных прав и права на участие в референдуме граждан Российской Федерации». Согласно пояснительной записке по замыслу авторов законопроекта предусматривается право политическим партиям отзывать членов избирательных комиссий, и представлять кандидатуру нового члена от соответствующей партии. На практике у избирательных объединений могут возникнуть трудности при реализации положений данного закона, в связи с тем, что из избирательных комиссий регионального уровня и центральной избирательной комиссии нельзя отзывать члена комиссии в первый и последний год работы, и в период объявленных выборов и референдумов. Учитывая, что на федеральном и региональном уровне каждый год идут избирательные кампании от муниципального до федерального уровня, отозвать члена комиссии на практике будет достаточно непросто. В мае 2012 года данный законопроект был принят в первом чтении и забыт. Пролежав длительное время в Государственной Думе Федерального Собрания без движения, он удивительным образом приобрел новое дыхание. В ходе обсуждения на профильном комитете в него были внесены поправки о возможности голосования несколько дней подряд (но не более трех дней). В ходе обсуждения данного законопроекта, представители оппозиционных думских фракций «Справедливая Россия», КПРФ и ЛДПР раскритиковали поправки, заявив, что нововведения ухудшают транспорентность голосования и остро возникает вопрос о легитимности выборов [5].
Несколько сотен членов избирательных комиссий выступили против трехдневного голосования из-за большой нагрузки. Вместо одного двенадцати часового рабочего дня, членам избиркомов предлагают три. При этом у большинства членов комиссий есть основное место работы. Говоря о мировой практике многодневного голосования, следует отметить, что все не так однозначно и в этом вопросе тоже существуют полярные мнения. Там где есть место многодневному голосованию, так или иначе, возникают вопросы с прозрачностью избирательного процесса.

Еще одна новация внесена в избирательный процесс, тем же Федеральным Законом №Ф3-267 «О внесении изменений в отдельные законодательные акты Российской Федерации» восьмое предложение абзаца первого пункта 4 статьи 30 «При проведении выборов в органы государственной власти субъекта Российской Федерации, референдума субъекта Российской Федерации, выборов в органы местного самоуправления, местного референдума на территории соответствующего субъекта Российской Федерации наблюдателем может быть гражданин Российской Федерации, обладающий активным избирательным правом на выборах в органы государственной власти, правом на участие в референдуме соответствующего субъекта Российской Федерации» Таким образом, лицам из другого субъекта Российской Федерации принять участие в качестве наблюдателей на выборах уже не получиться. Еще более странно, что при этом федеральным законодательством не запрещено баллотироваться кандидатом на выборы высшего должностного лица субъекта Российской Федерации, не имея там регистрации по месту жительства. Данная норма по инициативе фракции «Единая Россия» призвана затруднить «электоральный туризм» [4]. Наблюдатели смогут работать на выборах только в том субъекте страны, где они обладают активным избирательным правом.

Следует отметить, что серьёзные успехи оппозиционных кандидатов, во многом связаны, в том числе и с защитой результатов в день голосования, а это происходит во многом благодаря участию независимых наблюдателей. К примеру, под наблюдением большого электорального десанта из Москвы прошли выборы мэра города Ярославля, на которых в 2012 году победил оппозиционный кандидат Евгений Урлашов. В 2015 году «Единая Россия» под общественным контролем столичных активистов в Балтийске не получила ни одного мандата в совет депутатов городской Думы. Стоит вспомнить и выборы губернатора Хакасии в 2018 году, когда от КПРФ участвовали наблюдатели из соседних регионов, в итоге Валентин Коновалов стал губернатором. Аналогичным образом стала возможной победа в 2015 году на губернаторских выборах в Иркутской области коммуниста Левченко С.Г. Понимая, что движение россий- 
ской избирательной системы в сторону электронного голосования является развитием цифрового общества и определенным этапом технологического развития, мы в очередной раз становимся свидетелями законодательных инициатив, которые могут затруднить развитие политической системы, понизив и так не высокий уровень доверия граждан к институту выборов. Важно понимать, что выборы - это основной механизм смены власти в демократическом обществе, который дает надежды на перемены к лучшему в рамках действующего законо- дательства. Останется ли у граждан возможность изменить жизнь, остаться источником власти в государстве, создать почву для развития демократии вызывает большие вопросы. Остается только надеяться, что при всей насыщенности и быстроте законодательных изменений в избирательном праве, законодатель не забудет о необходимость сохранить открытость и прозрачность избирательных процессов, а в случае сомнений в данных новациях, необходимо оставлять прежние проверенные временем правовые основы.

\section{ЛИТЕРАТУРА}

1. Моторина В.0. Электронное голосование: опыт зарубежных стран и России / В.0. Моторина // Безопасность информационного пространства — 2017: XVI Всероссийская научно-практическая конференция студентов, аспирантов, молодых ученых. Екатеринбург, 12 декабря 2017 года. — Екатеринбург: Изд-во Урал. ун-та, 2018. - С. 270-273.

2. Правовое регулирование и практика электронного голосования в зарубежных странах. Научный журнал КубгАу№117(03), Савченко Марина Станиславовна заведующая кафедрой государственного и международного права, д.ю.н., профессор 2016 года. URL: http://ej.kubagro.ru/2016/03/pdf/17.pdf 1 yДK 342.84312 .00 .00 https://cyberleninka.ru/article/n/pravovoe-regulirovanie-i-praktika-elektronnogo-golosovaniya-v-zarubezhnyh-stranah

3. Овчинников В.А., Антонов Я.В. Некоторые аспекты обеспечения конституционного соответствия электронного голосования как части электронной демократии // Государственная власть и местное самоуправление. 2014. № 1

4. «0ткрытые Медиа», Дата доступа 16.07.2020 08:22 Госдума запрещает электоральный туризм. Наблюдатели не смогут контролировать выборы в «чужих» регионах Даниил Кузнецов

5. URL:https://openmedia.io/news/n3/gosduma-zapreshhaet-elektoralnyj-turizm-nablyudateli-ne-smogut-kontrolirovat-vybory-v-chuzhix-regionax/

6. Свободная Пресса, интернет ресурс: Дата: 17 июля 2020 года.URL: https://svpressa.ru/politic/article/271097/

7. Федеральный закон от 31.07.2020 N 267-Ф3 «0 внесении изменений в отдельные законодательные акты Российской Федерации»//СПС «КонсультантПлюс».

8. Электронное голосование на выборах в Мосгордуму в 2019 году. Доклад Романа Юнемана. Дата 2020 год. URL: https://drive.google.com/file/ d/1L9U2ssdjw_nRJMjBlzebhPDppfoWZgmJ/view

9. Актуальные комментарии. Опыт электронного голосования в зарубежных странах: технические сложности и восприятие нового. Валерий Прохоров Дата 8 Июня 2020 год. URL:http://actualcomment.ru/opyt-elektronnogo-golosovaniya-v-zarubezhnykh-stranakh-tekhnicheskie-slozhnosti-i-vospriyatie-novogo.html http://actualcomment.ru/opyt-elektronnogo-golosovaniya-v-zarubezhnykh-stranakh-tekhnicheskie-slozhnosti-i-vospriyatie-novogo.html

10. «Конституция Российской Федерации» (принята всенародным голосованием 12.12.1993 с изменениями, одобренными в ходе общероссийского голосования 01.07.2020) //СПС «КонсультантПлюс».

11. «Всеобщая декларация прав человека» (принята Генеральной Ассамблеей 00Н 10.12.1948) //СПС «КонсультантПлюс». 